\title{
The Paradox of Mixed Ownership Reform in State- owned Enterprises and Its Countermeasures
}

\author{
Tinghao Chen \\ China West Normal University \\ Nanchong, China 637000
}

\author{
Yang Tan \\ CPC Organization Committee Office of Shunqing District \\ Commission of Nanchong City \\ Nanchong, China 637000
}

\begin{abstract}
The ownership of state-owned enterprises does not refer to the ownership of "state", but to a common ownership formed by the transfer of ownership rights in individual ownership by the whole people. The retention of the residual claim by the whole people is a prerequisite for the establishment of joint ownership. However, the financial department's capital contribution from the state-owned capital and the surviving demand for dual status cannot guarantee the full realization of the residual claim right, which leads to the paradox of stateowned enterprise mixed ownership reform. State-owned shares should be divided into independent departments in the form of preferred shares, representing the whole people to exercise the residual claim rights, and finally forming a system of checks and balances between state-owned control rights, state-owned residual claims and private capital control rights.
\end{abstract}

Keywords-mixed ownership reform; residual claims; stateowned enterprises; countermeasure

\section{INTRODUCTION}

Property rights are the legal form of production relations. Therefore, the ownership of state-owned enterprises is not the ownership of "state", but a common ownership formed by the transfer of ownership rights in individual ownership by the whole people. This kind of transfer is based on the premise of retaining the residual claim to gain added value. In the current way of realizing property rights, the financial department represents the whole people to exercise the residual claim right, and on behalf of the whole people to transfer the ownership right in the individual ownership, which integrates the dual identity. This led to a paradox in the reform of mixed ownership. In order to deepen the mixed ownership reform of state-owned enterprises, this paradox must be effectively resolved. Therefore, this paper aims to propose the relevant countermeasures path by studying the causes and formation problems of the state-owned mixed ownership reform paradox.

\section{THE PARADOX OF STATE-OWNED ENTERPRISES' MIXED OWNERSHIP REFORM}

At present, deepening the reform of mixed ownership is the focus of state-owned enterprise reform. The existing related research points out the problems existing in the reform of state-owned mixed ownership from different aspects. Hu Jie (2014) and Guo Quanzhong (2015) pointed out that the reform of mixed ownership is faced with problems such as unclear positioning of the state-owned economy, loss of state- owned assets, and protection of property rights. To promote the reform of mixed ownership, first of all, according to the functional orientation and the role of status of different stateowned enterprises, it's important to perform classification reform, and secondly, it's necessary to transfer state-owned asset management system with the focus of the state capital management, and the state-owned asset management system shall be improved. At the same time, the conditions for nonpublic capital access should be relaxed. ${ }^{1,2}$ Zhang Zhaoguo (2016) believes that although the governance structure of state-owned enterprises has been established, the administrative problems of governance behaviors are still serious. The decision-making functions of internal governance, such as executive appointments and dismissals, compensation, equity incentives, etc., are still subject to main body of external governance; and many functions of external governance, such as the functions of the enterprise to carry out the society, are borne by internal governance. Therefore, it is necessary to improve the capital structure of state-owned enterprises and build a modern property rights system by absorbing non-public capital, expanding foreign investment, developing institutional investors, improving equity incentive mechanisms, and implementing preferential stocks and "share-for-debt" measures. ${ }^{3}$ Liu He (2016) pointed out that the current problems facing the reform of mixed ownership system are the problems of unclear status of the marketoriented state-owned enterprises, excessively widened stateowned economy layout, and low efficiency. ${ }^{4}$

If the problems existing in the mixed ownership reform of state-owned enterprises pointed out by the existing research are summed up, there are three main aspects: First, stateowned enterprises are still "one shareholder matters," and it is

Hu Jie. A New Round of State-owned Enterprise Mixed Ownership Reform: Problems and Suggestions [J]. China Development Watch, 2014,(11):32-35

Guo Quanzhong. Problems and Countermeasures for the Reform of State-owned Enterprises' Mixed Ownership System [N]. China Economic Times, 2015-04-14(005).

Zhang Zhaoguo, Chen Huadong, Zheng Baohong. Reflections on Several Issues in the Reform of State-owned Enterprises Mixed Ownership in the Perspective of Capital Structure [J]. Macroeconomic Research, 2016 , (01):86-92

4 Wang Miao. The National Development and Reform Commission Convened a Special Meeting on the Reform of State-owned Enterprise Mixed Ownership Reform [N]. China Reform News, 2016-10-10(001). 
difficult to establish a corporate governance structure that joint-stock enterprises should have; second, the problem of non-separation of government and business is still there.; the third is that the economic functions of state-owned enterprises are intertwined with social responsibilities, and the requirements of corporate governance, supervision and market-based competition mechanisms of mixed-ownership enterprises are contradictory.

The essence of these problems is a paradox: state-owned enterprises must fulfill their full social responsibilities to effectively prevent the loss of state-owned assets, which inevitably requires the government as a shareholder to occupy sufficient control in state-owned enterprises. Therefore, the problem of "one shareholder matters" is inevitable. On the contrary, to meet the market-oriented competition mechanism, improve the corporate governance and supervision of stateowned enterprises in order to improve operational efficiency, to achieve a true separation of government and enterprise, the government must be weakened as a shareholder in the control of state-owned enterprises, and the weakening of control will inevitably cause state-owned enterprises to face problems such as loss of assets and inadequate implementation of social responsibility.

To deepen the reform of mixed ownership of state-owned enterprises, this paradox must be effectively resolved. Therefore, the key issue to be solved in the reform of stateowned enterprises' mixed ownership is the shareholding structure. The State Council issued the "Opinions on the Development of Mixed-Ownership Economy in State-Owned Enterprises", clearly stating that the reform of state-owned enterprises' mixed ownership is to start from the establishment of a sound state-owned enterprise governance mechanism and supervision system, ultimately realizing the transformation of state-owned enterprise operating mechanism and the improvement of operational efficiency.

To solve this paradox of state-owned enterprise mixed ownership reform, it's necessary to jump out of the thinking that state-owned shares can only exist in three ways: absolute holding, relative holding and shareholding, so as to establish property rights arrangements of dynamic adjustment based on residual claims and preferred stocks.

\section{THE FORMATION OF STATE-OWNED ENTERPRISES MIXED OWNERSHIP REFORM PARADOX}

\section{A. Ownership Is the Legal Expression of Economic Relations}

Unlike contemporary Western economists, although Marx made an in-depth and scientific analysis of capitalist ownership and property rights, he did not define ownership and property rights in the most general or abstract sense. The ownership and property rights system studied by Marx is always a specific ownership and property rights system under a specific historical condition. The ownership system mentioned is the economic category and the economic system concerning the attribution of means of production. Ownership of production means is the basis of production relations, while the level of productivity development determines the relationship of production. The ownership of production means, which is the basis of production relations, determines the nature of the production relationship and the social system Moreover, it has a huge counter-productive effect on the development of productivity, promoting or hindering the development of productivity."

In Marx's economics research, Marx always regards rights of property as a kind of social relationship. At the same time, he also regards property rights as an economic relationship and economic rights (not a simple relation of will). Marx further raised the property right to the economic relationship expressed by the will of law. ${ }^{6}$ Since property rights represent economic relations, the subject of property rights should fundamentally be the person in the economic practice activities, not the abstract organization as the collection of people. The realization of property rights can depend on the institutional arrangement of the organization, but this does not mean that the organization can be regarded as the subject of the property itself.

In Marx's theory of property rights, the various rights of property are unified in some cases and belong to the property owner. In these cases, property ownership includes various rights to the property. Proprietary rights include a group of rights such as attribution, possession, use, dominance, and income rights in broad senses. And in narrow sense, ownership refers to a single attribution right. In many cases, ownership can be broken down and the various rights of property can be separated from each other. In these cases, property ownership generally does not include all the rights to the property. ${ }^{7}$ When the powers of property rights are separated, the way in which the property rights are realized by the structure of institutional arrangements of the organization determines the extent to which the rights of the property owners are realized.

\section{B. Distortion of the Ownership Structure of State-Owned Enterprises}

In the reform of state-owned enterprises, the exercise of the residual claims of the whole people is insufficient, which is the root of the mixed ownership reform paradox. For stateowned enterprises, that is, enterprises owned by the whole people, their funds contributor is not a collectively abstract country, but a collection of all people as natural persons. The ownership of state-owned enterprises is not the ownership of the "state", but the ownership of the whole people. In reality, it is expressed as a decentralized structure. The attribution rights of the individual's transfer of individual ownership can construct a common ownership, while retaining the residual ownership in order to gain the proliferation of value. The joint ownership consisting of the attribution rights transferred by the whole people isolates the control and management rights, which constitute the governance structure of the state-owned enterprises in "Fig. 1".

Li Qiqing.Marx's Theory of Ownership and Reform of Chinese Ownership[J].Marxism and Reality, 1999,06:4-7

Zhu Chunyan. Research on the Property Right Thought of Capital Theory[M]. Beijing: China Social Sciences Press. 2008:48

Wu Yifeng. Marx's Property Right Theory and the Reform of Stateowned Enterprise Property Rights[J]. Chinese Social Sciences, 1995,01:4-24 


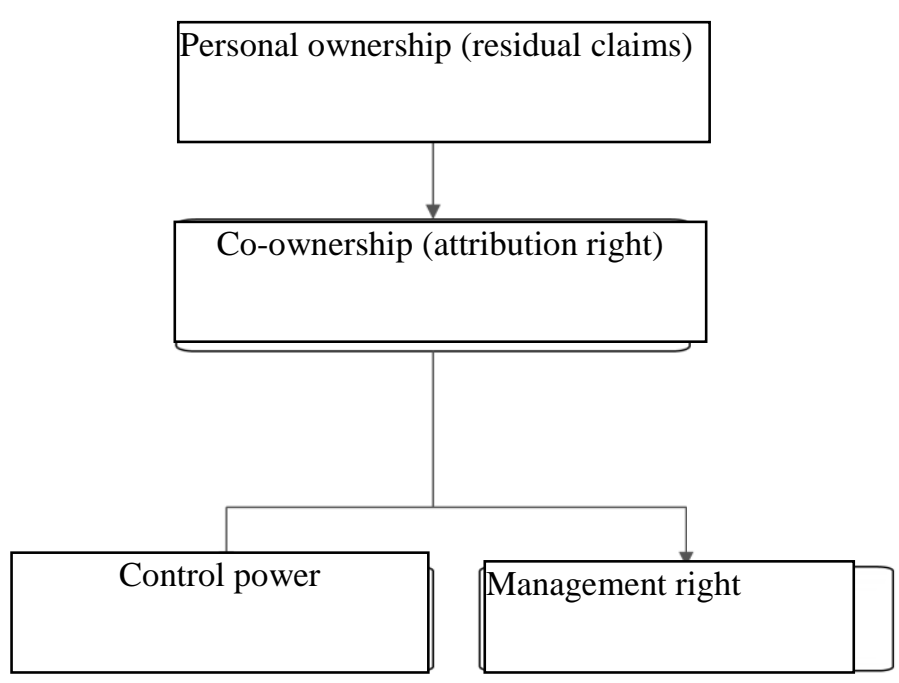

Fig. 1. Construction of ownership of state-owned enterprises.

As all-people ownership enterprises, state-owned enterprises are actually companies established by the whole people as funders to convert individual ownership into joint ownership. The representatives selected by the whole people exercise the control and management rights of the enterprise. Shareholders of the enterprises owned by the whole people "as a shareholder to contribute capital, it is not to deny itself, but to realize its own interests by choosing the social organization form of production that adapts to the development of productive forces." ${ }^{8}$ Therefore, in theory, after the state-owned enterprises realize the benefits, the government's after-tax profits paid by the state-owned enterprises should be used for the people to realize the residual claim of the whole people. The institutional arrangement of this process determines the degree of realization of the national residual claim rights, and at the same time determines the degree of control and supervision of the whole people as funders on the operational efficiency of state-owned enterprises.

Before the reform of state-owned enterprises, state-owned enterprises generally implemented the distribution system of "unified collection and expenditure", that is, the profits realized by enterprises were all turned over to the finances, and all the funds needed by enterprises were allocated by the state. In 1978, after the reform of state-owned enterprises with decentralization and profit-sharing as the main content, stateowned enterprises implemented profit retention. In 1988, the pilot of taxation and diversion was started. After the reform of profit and tax, the profit distribution form that the state-owned enterprises pay the net income to the state was instead by paying the income tax, tax adjustment and other forms of tax distribution to the state. After the implementation of the "contracting system" in the late 1980s, the method of contracting profits was used to replace the method of collecting income tax from state-owned enterprises. After two years of trials, the State Council officially began to compile state-owned capital operating budgets in 2010 to distribute the post-income profits of state-owned enterprises, ending the

\footnotetext{
8 Chen Yongzheng. Ownership Structure Theory [D]. Sichuan
} University, 2002. history of state-owned enterprises' full profits retention after tax. $^{9}$

In view of the entire historical process of state-owned enterprise reform, the various measures of state-owned enterprise reform have been carried out in three steps: first, to keep profits for state-owned enterprises to stimulate the enthusiasm of state-owned enterprises; second, to regulate the external taxation system environment of state-owned enterprises to improve the efficiency of state-owned enterprises; third, to pay profits after tax to realize the allpeople ownership of state-owned enterprises. When the development of state-owned enterprises is hard, the focus of state-owned enterprise reform is to maintain profits for stateowned enterprises and regulate the management system of state-owned enterprises to improve efficiency. After the stateowned enterprises have achieved certain benefits, the government collects the profits of the state-owned enterprises after tax and uses them for public utilities.

The logic of this kind of state-owned enterprise reform is always carried out under the framework of the central and local government SASAC's supervision of the state-owned enterprises on behalf of the funders, and the Ministry of Finance and other local financial departments on behalf of the whole people to exercise the residual claim of state-owned assets. Among them, the central and local financial departments are responsible for the collection of state-owned capital operating budget revenues, and for the allocation of state-owned capital operating budget expenditures. In fact, the financial department represents the attribution right of the transferred individual ownership of the whole people, and exercise the residual claim on behalf of the whole people, combining two identities. Therefore, in the expenditure and income of state-owned assets, there is no independent institutional arrangement for exercising the residual claim, so it is difficult to guarantee the full realization of the residual claim of the whole people. The dualization of this identity of the financial sector in state-owned assets is the root cause of mixed ownership reform paradox. Central and local financial departments' income and expenditure on state-owned assets

As far as the reality is concerned, in the operating budget of the central or local state-owned capital, the government, as the representative of the whole people exercising the residual claim rights, the expenditure that transfers the state-owned capital income into the general public budget and invest in public services actually still accounts for a small part. Taking the central state-owned capital as an example, in the "Notes on the Final Account of Central State-owned Capital Management in 2015" issued by the Ministry of Finance, the central government's state-owned capital operating budget expenditure was 123.536 billion Yuan at its level. Among them, the total number of accounts allocated to the general public budget for the protection and improvement of people's livelihood is only 23 billion Yuan, accounting for only $18.62 \%$ of the total expenditure of the state-owned capital

\footnotetext{
9 Li Yan, Tang Zhuo. Profit Distribution of State-owned Enterprises and Improvement of State-owned Capital Operation Budget_-Analysis of Public Sharing Based on Public Resources Profits[J].Journal of Central University of Finance and Economics, 2013,06:7-12.
} 
operation at the central level. The final amount of state-owned capital injection was 51.439 billion Yuan, accounting for $41.64 \%$ of the total expenditure of state-owned capital management at the central level.

TABLE I. STATE-OWNED CAPITAL OPERATING INCOME AND EXPENDITURE

\begin{tabular}{|c|c|c|}
\hline & 2015 & 2016 \\
\hline $\begin{array}{l}\text { Central state-owned capital operating total } \\
\text { income }\end{array}$ & 1612.92 & 1430.17 \\
\hline $\begin{array}{l}\text { Central state-owned capital operation total } \\
\text { expenditure }\end{array}$ & 1359.67 & 1450.61 \\
\hline Of which: transfer to the general public budget & 230 & 246 \\
\hline Local transfer payment & 124.3 & 513.53 \\
\hline Local state-owned capital operating income & 1071.54 & 1685.2 \\
\hline Local state-owned capital operating expenses & 843.2 & 1234.38 \\
\hline Of which: transfer to the general public budget & - & 246.91 \\
\hline
\end{tabular}

a. Source: report of the Ministry of Finance in the fourth, fifth session of the Twelfth National People's

In terms of comprehensive central and local state-owned capital, the total revenue of central state-owned capital operations in 2015 was 161.292 billion Yuan, with an expenditure of 135.967 billion Yuan. Among them, the central government's expenditure at this level was 123.537 billion Yuan, including the transfer of the general public budget of 23 billion Yuan to protect the people's livelihood; and the local transfer payment of 12.43 billion Yuan. The central stateowned capital operating budget would be carried over to the next year's expenditure of 39.723 billion Yuan. The local state-owned capital operating budget had a revenue of 94.724 billion Yuan. Plus the local transfer payment income of 12.43 billion Yuan from central state-owned capital operating budget, the total income was 107.154 billion Yuan. The local state-owned capital operating budget expenditure was 84.32 billion Yuan. In 2016, the central state-owned capital operating budget revenue was 143.17 billion Yuan, with an expenditure of 145.061 billion Yuan. Among them, the central government's expenditure at this level was 93.708 billion Yuan; the local transfer payment was 51.353 billion Yuan; and the general public budget transfer was 24.6 billion Yuan, and the next year's expenditure was carried over with 12.803 billion Yuan. The local state-owned capital operating budget had an income of 117.167 billion Yuan and expenditure of 123.438 billion Yuan. Among the expenditures, 24.691 billion Yuan was transferred to the general public budget.

\section{The COUnTERmeasure Path to SOlve the MiXed OWNERSHIP PARADOX}

In theory, the problem of insufficient exercise of residual claims is mainly due to improper property rights arrangements. Under the current system of state-owned assets, the central and local state-owned assets supervision and management committees exercise control over state-owned enterprises on behalf of the whole people. The Ministry of Finance and other local departments delegate the whole people to transfer individual ownership and exercise the residual claim for stateowned assets. That is to say, the financial department acts as a representative of the transfer of individual ownership by the whole people and as a representative of the whole people to exercise the residual claim. Under the current reform of stateowned enterprise mixed ownership, after the introduction of private capital, a multi-level principal-agent relationship must be formed between the whole people and governments at all levels and business operators. To protect the residual claims of the whole people, it's important to further standardize the management system of state-owned enterprises' operating budgets, improve the property rights arrangements of stateowned enterprises, and further promote the corporate governance reform of state-owned enterprises. Among them, the key is to independently supervise the government's departments that exercise control and the departments that exercise the residual claims to safeguard the residual claims of the whole people, and promote the smooth advancement of mixed ownership reform. The core of improving state-owned asset management system is to reposition the status and responsibilities of the SASAC, making it a specialized agency that supervises the actions performing the duties of the investor on behalf of the same-level government. ${ }^{10}$

\section{A. Classified Relaxation of Non-public Capital Access Conditions}

The study pointed out that state-owned holding companies are significantly more profitable than state wholly-funded companies, but still weaker than private wholly-funded enterprises. ${ }^{11}$ In order to amplify the function of state-owned capital, maintain and increase value, and improve competitiveness, state-owned enterprises must deepen the reform of mixed ownership, lower the threshold, and introduce non-public capital. For a small number of stateowned enterprises, state-owned capital investment companies, and state-owned capital operating companies that are not suitable for introducing non-public capital because they involve national security, they should improve the stateowned capital efficiency by improving the investment management system and strengthening corporate governance and supervision. For state-owned enterprises in key industries and key areas involving the lifeline of the national economy, it is necessary to liberalize restrictions on the proportion of shares held by society and private capital, and absorb more social capital to participate in the reform of mixed ownership of state-owned enterprises. For important state-owned enterprises involved in pillar industries and high-tech industries, it is necessary to fully relax conditions, lower the threshold, unify the market access system, implement a "negative list" system, and delineate a few red line lists that are not suitable for mixed ownership industries and enterprises. Even in the natural monopoly industry, it is necessary to distinguish between natural monopoly links and non-natural monopoly links, gradually liberalize non-natural monopoly links, and play the role that non-public capital should play in the reform of mixed ownership. For stateowned enterprises whose state-owned capital does not need to be controlled and can be controlled by social capital, stateowned capital should reduce its shareholding in a timely manner, relax non-public capital access, and allow non-public

10 Wang Xinhong. On the Improvement of Enterprise State-owned Assets Management System - Also on the Positioning Adjustment of Stateowned Assets Supervision and Administration Commission [J]. Politics \& Law, 2015, (10):129-141.

11 Liu Xiaolu. Five Key Issues in the Reform of State-owned Mixed Ownership System [N]. China Securities Journal, 2015-10-26(A12). 
sector resources to participate in the provision of public goods by deepening PPP and other means to create conditions for non-public capital to fully play its role.

\section{B. Prioritizing Stocks to Protect Residual Claims}

After relaxing the conditions for non-public capital access, the focus of deepening the reform of state-owned mixed ownership is the arrangement of shareholding structure. Some studies have pointed out that the relationship between productivity and the proportion of state-owned assets is not a simple monotonous relationship, but an "inverted U-shaped" trend that rises and then falls as the proportion of state-owned assets declines. ${ }^{12}$ This shows that the mutual checks and balances between state-owned capital itself, state-owned capital and non-public capital are particularly important. It is necessary to break the disposition pattern of the dual identity of the representatives of the financial sector and the representatives of the residual claims to protect the residual claims of the entire people as funders. To solve the mixed ownership reform paradox, the preferred stocks should be divided to establish a residual claim department independent of the financial department, differentiate the financial sector from multiple identities, and establish a dynamic adjustment mechanism.

Preferred stock refers to an equity held by its shareholders by abandoning the right to vote and to be elected to obtain the preferential rights of profit distribution and distribution of surplus property. Under normal circumstances, the company's equity capital is mainly composed of common stock. Common stocks have both the right to vote and the right to be elected. Shareholders bear the risk of business operations based on the proportion of equity. Preferred stocks are different from ordinary shares in that they give up the right to a stable income because they give up voting rights. Regardless of whether the company is profitable or not, the priority shareholders can obtain a predetermined rate of return and do not assume the business risks of the company. Therefore, the shares of state-owned enterprises are separated in the form of preferred shares, and the department that exercises the residual claim is established, independent of the financial department. The department that exercises the residual claim right independently of the financial department shall, in accordance with the proportion of the preferred shares, use the proceeds of the state-owned enterprises in public service projects such as education, social security, medical care and poverty alleviation to ensure the realization of the residual claims of the whole people. The state-owned capital shares remaining after the division of preferred shares are managed by the financial department and exercise the control of state-owned capital. The ratio of preferred stocks to common stocks is dynamically adjusted based on the share of private equity. When the state-owned capital is too large, hindering the efficiency of state-owned enterprises and the separate implementation of government and enterprises, it's necessary to increase the proportion of preferred stocks, and vice versa, the proportion of preferred stocks should be reduced. So, a mutually balanced equity arrangement

12 Liu Xiaolu. Five Key Issues in the Reform of State-owned Mixed Ownership System [N]. China Securities Journal, 2015-10-26(A12). consisting of preferred shares, common stock and private economic shares can be found in "Fig. 2", "Fig. 3".

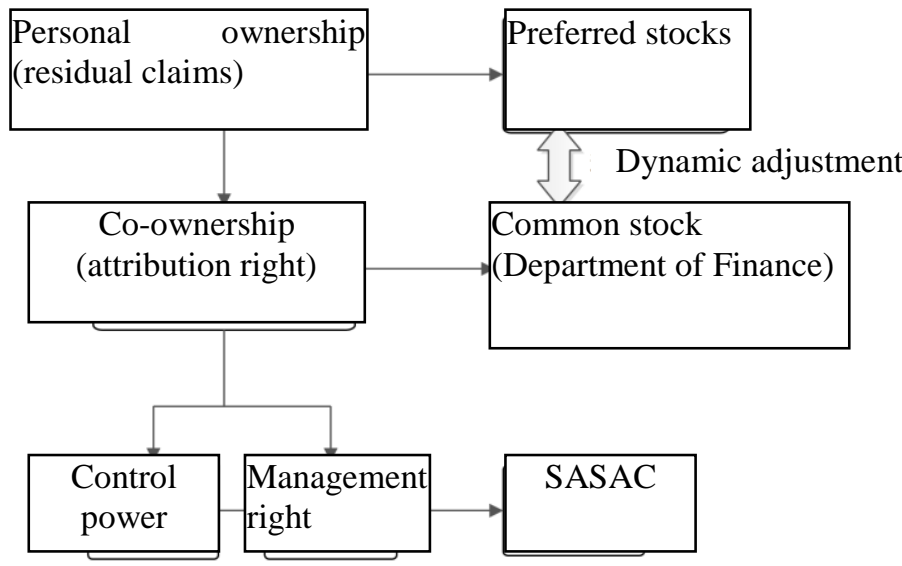

Fig. 2. Solution logic of mixed ownership reform paradox.


Fig. 3. Dynamic equity arrangement

\section{Improving the Corporate Governance Structure of State- owned Enterprises}

Deepening the mixed ownership of state-owned enterprises must realize the diversification of investment entities, and the composition of multi-property entities must require the appropriate board structure and decision-making process, and it also requires the establishment of a sound information disclosure system. According to the modern corporate governance theory, state-owned enterprises should deepen the reform of mixed ownership, and should form a manager responsibility system under the leadership of the board of directors, guarantee the directors' power in major decision-making of enterprises, and clarify the relationship and duties between the board of directors and the manager. By dividing the preferred shares, the mutually-balanced arrangement of stock rights consisting of preferred shares, common shares and private economic shares is formed. Then, the common stocks should be based on the proportions held by the SASAC on behalf of the whole people to set up corresponding seats in the board of state-owned enterprises. Public capital should also establish corresponding seats in proportion to ensure the non-public capital participation in decision-making. ${ }^{13}$

Secondly, to deepen the reform of mixed ownership of state-owned enterprises, we should establish an incentive and

13 Yang Hongying, Tong Lu. On Corporate Governance of Stateowned Enterprises under the Reform of Mixed Ownership[J]. Macroeconomic Research, 2015, (01):42-51. 
restraint mechanism for the management of state-owned enterprises. The department exercising the residual claim shall exert the review and supervision role of the control department and non-public capital represented by the SASAC, and grant the right to exercise the residual claim right for the accountability of the state-owned enterprise. Based on this, it's necessary to adjust the personnel arrangement and shareholding ratio of the state-owned capital control department. At the same time, it is important to deepen management shareholding, establish a manager performance evaluation mechanism, and de-administrative management of corporate executives to ensure the standardized operation of mixed-ownership state-owned enterprises.

In addition, deepening the reform of mixed ownership of state-owned enterprises should improve the information disclosure system of state-owned enterprises with mixed ownership. The mutually-balanced equity arrangement of preferred stocks, common stocks and private economic stocks relies on a transparent SOE disclosure system. The experience of the management and operation of state-owned enterprises around the world shows that ensuring adequate information disclosure and transparency at the enterprise level is a necessary way to improve the management and efficiency of state-owned enterprises. Improving the transparency of information disclosure of state-owned enterprises is conducive to the public's clear understanding of the performance and operation of state-owned enterprises, and arousing the attention and supervision of the people and the media on state-owned enterprises. ${ }^{14}$

\section{CONCLUSION}

Property rights are the legal form of the production relationship. Therefore, the ownership of state-owned enterprises is actually a common ownership that can be formed by the right of attribution, which belong to the ownership of the individual transferred by the whole people. This kind of transfer is based on the premise of retaining the residual claim and gaining value. In the current way of realizing property rights, the financial department represents the whole people to exercise the residual claim right, and on behalf of the whole people to transfer the attribution right in individual ownership, integrating the dual identity. In the reform of mixed ownership, this situation leads to a paradox: on the one hand, the limitations of state-owned capital itself need to be resolved in cooperation with non-public capital. On the other hand, state-owned capital must avoid losses caused by the introduction of non-public capital. This paradox in property rights arrangement is determined by the unity of opposites of state-owned capital and non-public capital. The root cause lies in the failure to fully guarantee the realization of the residual claims of the whole people. The department in which the state-owned shares are established in the form of preferred shares shall be established to exercise the residual claim, and a dynamic system of checks and balances between the financial sector and private capital based on common shares shall be established. In this way, by improving the information disclosure system and deepening the incentive and restraint mechanism of enterprise management, the multilevel agency problem between the state, the government and the business operators in the state-owned economy is transformed into the mutual checks and balances of stateowned control, state-owned residual claims and private capital control between powers, which not only overcomes the stateowned capital monopoly in a certain degree, but also adapts to the policy situation of state-owned enterprise mixed ownership reform, and to some extent solves the multi-level agency problem under the condition of state-owned enterprise mixed ownership reform and the insufficient exercise of the national residual claim.

\section{REFERENCES}

[1] Hu Jie. A New Round of State-owned Enterprise Mixed Ownership Reform: Problems and Suggestions [J]. China Development Watch, 2014, (11)

[2] Zhang Zhaoguo, Chen Huadong, Zheng Baohong. Reflections on Several Issues in the Reform of State-owned Enterprises Mixed Ownership in the Perspective of Capital Structure[J]. Macroeconomic Research, 2016, (01).

[3] Li Yan, Tang Zhuo. Profit Distribution of State-owned Enterprises and Improvement of State-owned Capital Operation Budget - Analysis of Public Sharing Based on Public Resources Profits[J].Journal of Central University of Finance and Economics,2013,06.

[4] Wu Yifeng. Marx's Property Right Theory and the Reform of Stateowned Enterprise Property Rights[J]. Chinese Social Sciences, 1995

[5] Chen Yongzheng. Ownership Structure Theory [D]. Sichuan University, 2002.

[6] Guo Quanzhong. Problems and Countermeasures for the Reform of State-owned Enterprises' Mixed Ownership System [N]. China Economic Times, 2015-04-14(005)

[7] Wang Miao. The National Development and Reform Commission Convened a Special Meeting on the Reform of State-owned Enterprise Mixed Ownership Reform [N]. China Reform News, 2016-10-10(001).

[8] Wang Xinhong. On the Improvement of Enterprise State-owned Assets Management System - Also on the Positioning Adjustment of Stateowned Assets Supervision and Administration Commission[J]. Politics \& Law, 2015, (10): 129-141.

[9] Liu Xiaolu. Five Key Issues in the Reform of State-owned Mixed Ownership System [N]. China Securities Journal, 2015-10-26 (A12).

[10] Yang Hongying, Tong Lu. On Corporate Governance of State-owned Enterprises under the Reform of Mixed Ownership[J]. Macroeconomic Research, 2015, (01): 42-51.

[11] Lu Tong, Dang Yin. Improving Corporate Governance of State-owned Enterprises: International Experience and Its Enlightenment [J]. International Economic Review, 2015, (04): 134-149+8.
14 Lu Tong, Dang Yin. Improving Corporate Governance of Stateowned Enterprises: International Experience and Its Enlightenment [J] International Economic Review, 2015, (04):134-149+8. 